\title{
Differences in Growth Performance and Protein Metabolism- Related Parameters of Broiler Chickens and Native Chickens (Niigata Jidori)
}

\author{
Mohammad Ataur Rahman, Ryozo Takada* \\ Graduate School of Science and Technology, Niigata University, 8050 Igarashi 2 nocyo, Niigata, Japan \\ *Corresponding Author: Ryozo Takada, Graduate School of Science and Technology, Niigata \\ University, 8050 Igarashi 2 nocyo, Japan, 950-2181, Email: ryozo@agr.niigata-u.ac.jp
}

\begin{abstract}
This study was conducted to compare broilers and local chickens (Niigata Jidori) in terms of growth performance and protein metabolism-related parameters. Twenty 14-day-old chicks were housed individually in wire cages, fed experimental diets, and provided water adlibitum for 2 weeks. Growth performance, nitrogen retention, concentrations of free amino acids in muscles, as well as mRNA expression of liver IGF-1, breast muscle atrogin-1, and proteasome C2 subunit were determined. Body weight gain, feed intake, and feed efficiency were significantly higher $(P<0.01)$ in broilers than in Niigata Jidori. Muscle weights (breast and thigh) and nitrogen retention were significantly higher $(P<0.05)$ in broilers than in Niigata Jidori. Concentrations of free amino acids, viz., Asp ,Glu, Ala, Cys, Tyr, Lys, and Arg in breast muscle were significantly higher $(P<0.05)$ in broilers than in Niigata Jidori. No significant differences were found in concentrations of Thr, Ser, Gly, and Val, Met, Ile, Leu, Phe, and His. There were no significant differences in mRNA expressions of liver IGF-I, breast muscle atrogin-1, and proteasome C2 subunit between broilers and Niigata Jidori. The growth performance of broiler and Niigata Jidori varied significantly but there was no change in mRNA expression related to protein metabolism between the two breed.
\end{abstract}

Keywords: Niigata Jidori; Broiler; Growth Performance; Gene Expression

\section{INTRODUCTION}

There are approximately fifty recognized breeds of native chicken in Japan and most of them were breed frothier special plumage and fighting traits. The Japanese native chicken, Niigata Jidori, is not included as one of these recognized breeds but is available in the Niigata prefecture of Japan. Niigata Jidoriis bred from Plymouth Rock and the hybrid of Tomaru and Nagoya [1], like HinaiJidori in Hinai area in North Akita prefecture of Japan. Hinaidori is one of the famous Japanese memorial native chickens. Since eating memorial native chickens in Japan is prohibited, F1 of Hinaidori and Rhode Island Red called HinaiJidori, is consumed instead. The meat of HinaiJidoriis palatable and delicious in local dishes, like Kiritampo. Fujimura et al [2] have shown that the meat of HinaiJidori is tastier than that of broiler chickens. Likewise, the meat of Niigata Jidori is also much tastier than broiler chicken meat. Market price of Niigata Jidori is higher than that of broiler owing to its good taste. In a number of studies, growth trend parameters have been found to be highly heritable $[3,4,5]$. However, extensive research has not been done to determine the financial viability of rasing Japanese native chicken breeds. Their growth and other production parameters have also not been sufficiently studied.

Fujimura et.al [6] reported that there were no significant differences in amino acid concentration in the meat of Hinai Jidori and broiler, except for cysteine and methionine. The levels of free amino acids in the thigh meat of 8weeks-old broilers were significantly higher than those of twenty-two weeks-old Hinai Jidori [7]. Saneyasu et al. [8] reported the mRNA levels of IGF-I and atrogin-1 - which are factors related to protein metabolism - in breast muscle in 7- to 49-day-old broiler chickens IGF-I is known to stimulate protein synthesis and inhibit protein break down. In contrast, atrogin-1is a factor that stimulate proteolysis. Liver IGF-1 mRNA levels gradually decreased while muscle atrogin-1 mRNA levels increased with age.

Commercial chicken feed is mainly composed of corn and soybean meals. The global demand for corn in animal feed and fuel production is 
Differences in Growth Performance and Protein Metabolism-Related Parameters of Broiler Chickens and Native Chickens (Niigata Jidori)

increasing rapidly. Several studies have demonstrated that rice has the potential to offset this demand as a substitute for corn in poultry feed $[9,10$, and 11]. Better growth performance and nutrient digestibility can be obtained in broiler chickens if corn is replaced by rice with no known negative side effects. Replacing corn with rice might be a cost-effective and novel strategy for rearing both indigenous and hybrid broiler chickens. Thus, in this study, experimental diets were $20 \%$ rice.

The objectives of the present study were to clarify differences ingrowths performance, tissue weights, nitrogen retention, free amino acid concentrations in breast muscle, and mRNA expression of liver IGF-I, breast muscle atrogin-1, and proteasome $\mathrm{C} 2$ subunit between broiler chickens and Niigata Jidori.

\section{Materials AND Methods}

\subsection{Animal Care}

All animal experiments were conducted in compliance with the protocol reviewed by the Institutional Animal Care and Use Committee and approved by the President of Niigata University (Permit Number: Niigata Univ. Res.229-3).

\subsection{Bird Husbandry, Diets, and Experimental Desighn}

Two types of chicken were used in this experiment Niigata-Jidori and Chunky broiler strain. One-day-old Niigata Jidori was purchased from Niigata Prefectural Animal Industry Research Center. Chunky broiler chicks were obtained from a local trading company. Chicks were reared under identical environmental conditions in the same house for 2 weeks with free access to feed (commercial broiler grower containing $22 \% \mathrm{CP}$ and $3050 \mathrm{kcal} \mathrm{ME} / \mathrm{kg}$ ) and water. Twenty birds of 14-days-old (10Niigata Jidori and 10 Chunky broilers) were individually housed in battery cages with wire-mesh flooring and had free access to feed and water during the 2week-longsexperimental period.

The birds were kept under $24 \mathrm{~h}$ lighting programs throughout the experiment. The temperature was maintained at $29^{\circ} \mathrm{C}$ on the first day, and lowered by $1^{\circ} \mathrm{C}$ every 3 days, to a final temperature of $24^{\circ} \mathrm{C}$. Body weight gain (BWG), and feed intake (FI) were recorded weekly and feed efficiency (FE) was calculated from BWG divided by FI. The composition of basal diet is presented in Table 1 . The diet was formulated to meet or exceed nutrient recommendations for Ross-broiler chickens [12].

Table1: Composition and nutrient content of basal diets

\begin{tabular}{|l|l|}
\hline \multicolumn{1}{|c|}{ Ingredients } & \\
\hline corn & 24.55 \\
\hline rice & 25.00 \\
\hline soybean meal & 38.00 \\
\hline corn gluten meal & 3.00 \\
\hline oil & 5.00 \\
\hline Dicalcium phosphate & 1.74 \\
\hline Calcium carbonate & 1.21 \\
\hline Salt & 0.50 \\
\hline Lysine-HCl & 0.20 \\
\hline DL-methionine & 0.40 \\
\hline Threonine & 0.10 \\
\hline Choline chloride & 0.10 \\
\hline Premix1 & 0.20 \\
\hline Total & 100.00 \\
\hline CP & 24.55 \\
\hline Lys & 1.42 \\
\hline Thr & 0.96 \\
\hline Met+Cys & 1.15 \\
\hline ME $(\mathrm{kcal} / \mathrm{kg})$ & 3128 \\
\hline
\end{tabular}

Provided the following ( per $\mathrm{kg}$ of diet ) :Mn, 100ng; Zn,100ng; Fe, 40ng; Cu,15ng; I, Img; Vitamin A, 130 IU; Vitamin D, 35,000IU; Vitamin E, 80IU; Vitamin K,4mg; Thiamine monohydrate,4mg; riboflavin, 9mg; Vitamin B6 64mg; Vitamin B12, 0.02mg; pantothenate, 15mg; nicotinamido60mg; folic acid, $2 \mathrm{mg}$; biotino.15mg
2.3.Sample Collection and Weight Measurement
The excreta were collected during the last5 days of the experimental period and stored at $-30^{\circ} \mathrm{C}$ 
until analysis of nitrogen retention. All birds were killed by exsanguinations and dissected.

Right side breast and thigh muscle weights, and liver weights were recorded. Samples of liver and breast muscle were immediately removed, frozen in liquid nitrogen and stored at $-80^{\circ} \mathrm{C}$ until analysis.

\subsection{Nitrogen Retention Analysis}

Nitrogen balance trials were performed by a total collection procedure. Before analysis, excreta samples were thawed, dried at $60^{\circ} \mathrm{C}$ for $24 \mathrm{~h}$ and finely ground. The total nitrogen content in the samples was measured using a carbon/nitrogen analyzer (SUMIKA NC-90A, SUMITOMO CHEMICAL Co., Ltd, Tokyo, Japan).

\subsection{Free Amino Acids Concentrations Measurement}

For analyzing the concentration of free amino acids (FAA) in the breast muscle, $1.0 \mathrm{~g}$ of muscle tissues were finely cut using scissors and kept on icein9 $\mathrm{ml}$ of $3.5 \%$ sulfosalicylic acid and homogenized using a polytron-type homogenizer. Then the mixtures were refrigerated for $48 \mathrm{~h}$. The mixtures were centrifuged at $23,000 \times \mathrm{g}$ for $30 \mathrm{~min}$ at $4^{\circ} \mathrm{C}$, and Table2: Gene and related primers

\begin{tabular}{|l|l|}
\hline \multicolumn{1}{|c|}{ Genes } & \multicolumn{1}{c|}{ Primer sequence } \\
\hline IGF-I & F:5'-GCTGCCGGCCCAGAA-3' \\
& R:5'-ACGAACTGAAGAGCATCAACCA-3' \\
\hline Atrogin-1 & F:5'-ACGAACTGAAGAGCATCAACCA-3' \\
& R:5'-ACGAACTGAAGAGCATCAACCA-3' \\
\hline Proteasome C2 subunit & F:5'AACACACGCTGTTCTGGTTG3' \\
& R:5'-CTGCGTTGGTATCTGGGTTT-3' \\
\hline \multirow{2}{*}{ GAPDH } & F:5'CCTCTCTGGCAAAGTCCAAG3' \\
& R:5'CATCTGCCCATTTGATGTTG3' \\
\hline
\end{tabular}

\subsection{Statistical Analysis}

Data are presented as means \pm SEM. Data were analyzed using t-test. P-value $<0.05$ was considered statistically significant and a tendency toward significance was considered when the P-value was $>0.05$ but $<0.10$.

\section{Results}

\subsection{Growth Performance}

The results of growth performance are shown in Table 3. The average initial weight of Niigata

Table3: Differences of growth performance in broiler and Niigata Jidori the top clear layer of the mixture was removed using a syringe and filtered through a $0.45 \mu \mathrm{m}$ cellulose nitrate filter. The samples were stored at $-30^{\circ} \mathrm{C}$ in a freezer until analysis. Free amino acids concentrations in the breast muscle were analyzed via HPLC (LC-10A system, Shimazu, Kyoto) using shim-Pak amino-Na column.

\section{6.mRNA Isolation and Real Time PCR Analysis}

mRNA expression of liver IGF- I, breast muscle atrogin-1 and proteasome $\mathrm{C} 2$ subunit were measured in liver and breast muscle samples. Total RNA was extracted using TRIzol Reagent (Invitrogen Life Technologies, USA) according to the manufacturer's protocols. cDNA was synthesized from $200 \mathrm{ng} / \mu \mathrm{l}$ of total RNA using ReverTra Ace qPCR RT Master Mix with gDNA Remover (TOYOBO). The sequences of the forward and reverse primers are shown in Table 2. Gene expression was measured by realtime PCR using an MJ Mini Personal Thermal Cycler (Bio-rad) with SsoFast EvaGreen Supermix (Bio-rad). Glyceraldehyde-3phosphate dehydrogenase (GAPDH) expression was used as an internal control.

\begin{tabular}{|l|l|l|l|}
\hline & \multicolumn{1}{|c|}{ Broiler } & \multicolumn{1}{c|}{ Jidori } & \multicolumn{1}{c|}{ P-value } \\
\hline Initial body wt. & $248 \pm 6$ & $165 \pm 1$ & $<0.001$ \\
\hline Body Weight Gain (g/d)0-1wk & $66 \pm 3$ & $18 \pm 1$ & $<0.001$ \\
\hline $1-2 \mathrm{wk}$ & $89 \pm 4$ & $22 \pm 1$ & $<0.001$ \\
\hline
\end{tabular}


Differences in Growth Performance and Protein Metabolism-Related Parameters of Broiler Chickens and Native Chickens (Niigata Jidori)

\begin{tabular}{|l|l|l|l|}
\hline $0-2 w k$ & $156 \pm 6$ & $40 \pm 2$ & $<0.001$ \\
\hline Feed Intake (g/d) & & & \\
\hline $0-1 w k$ & $74 \pm 3$ & $41 \pm 3$ & $<0.001$ \\
\hline $1-2 w k$ & $119 \pm 6$ & $45 \pm 3$ & $<0.001$ \\
\hline $0-2 w k$ & $192 \pm 6$ & $86 \pm 6$ & $<0.001$ \\
\hline Feed Efficiency (gain/feed) & & & \\
\hline $0-1$ wk & $0.92 \pm 0.05$ & $0.45 \pm 0.04$ & $<0.001$ \\
\hline $1-2 w k$ & $0.75 \pm 0.03$ & $0.50 \pm 0.03$ & $<0.001$ \\
\hline $0-2 w k$ & $0.86 \pm 0.05$ & $0.47 \pm 0.02$ & $<0.001$ \\
\hline
\end{tabular}

Values are mean $\pm S E n=10$

\subsection{Tissue Weight}

Muscle weights (breast andthigh) and liver weights were shown in Table 4. Breast muscle and thigh muscle weights were significantly

Table4: Tissue weights in broiler and Niigata Jidori higher $(\mathrm{P}<0.01)$ in broilers than in Niigata Jidori.

Similarly, liver weights varied significantly $(\mathrm{P}<$ 0.01 ) between broilers and Niigata Jidori.

\begin{tabular}{|c|c|c|c|c|}
\hline & \multicolumn{2}{|r|}{ Broiler } & \multirow[t]{2}{*}{ Jidori } & $P$-value \\
\hline Liver weight (g) & \multicolumn{2}{|l|}{$32 \pm 1$} & & $<0.01$ \\
\hline Breast muscle & \multicolumn{2}{|l|}{$73 \pm 4$} & $9 \pm 0.4$ & $<0.01$ \\
\hline Thigh muscle & \multicolumn{2}{|c|}{$113 \pm 5$} & $35 \pm 1$ & $<0.01$ \\
\hline \multicolumn{5}{|l|}{ Mean \pm SE $n=10$} \\
\hline \multicolumn{3}{|c|}{$\begin{array}{l}\text { Table5 shows the results of nitrogen retention in } \\
\text { broilers and Niigata Jidori. Nitrogen retention } \\
\text { Table5: Nitrogen retention in broiler and Niigata Jidori }\end{array}$} & \multicolumn{2}{|c|}{$\begin{array}{l}\text { was significantly higher in broiler than in } \\
\text { Niigata Jidori when expressed in percentage } \\
(\mathrm{P}<0.05) \text { aswell as g/days, }(\mathrm{P}<0.01) \text {. }\end{array}$} \\
\hline & & \multirow{2}{*}{$\frac{\text { Broiler }}{72.6 \pm 3.5}$} & Jido & $P$ - value \\
\hline Nitrogen retention ( \% ) & & & $57.1 \pm 5.0$ & $<0.05$ \\
\hline Nitrogen retention ( g / days) & & $3.32 \pm 0.16$ & $0.98 \pm 0.09$ & $<0.001$ \\
\hline Mean \pm SE $n=10$ & & & & \\
\hline
\end{tabular}

\subsection{Free Amino-Acid Concentrations}

Free amino acid concentrations in the breast muscle of broiler chickens and Niigata Jidori are shown in Table 6. The concentrations of Asp, Glu, Ala, Cys, Tyr, Lys, and Arg were

Table6: Free amino acids concentration in breast muscle of broiler and Niigata Jidori

\begin{tabular}{|l|l|l|l|}
\hline & \multicolumn{1}{|c|}{ Broiler } & \multicolumn{1}{c|}{ Jidori } & \multicolumn{1}{c|}{-value } \\
\hline Asp & $0.65 \pm 0.07$ & $0.40 \pm 0.07$ & $<0.05$ \\
\hline Thr & $0.92 \pm 0.14$ & $0.98 \pm 0.02$ & \\
\hline Ser & $1.23 \pm 0.16$ & $0.88 \pm 0.16$ & $<0.05$ \\
\hline Glu & $2.35 \pm 0.32$ & $1.44 \pm 0.26$ & \\
\hline Gly & $0.97 \pm 0.22$ & $0.53 \pm 0.10$ & $<0.01$ \\
\hline Ala & $2.41 \pm 0.25$ & $0.80 \pm 0.12$ & \\
\hline Val & $0.18 \pm 0.03$ & $0.25 \pm 0.04$ & $<0.05$ \\
\hline Cys & $7.63 \pm 1.48$ & $1.34 \pm 0.32$ & \\
\hline Met & $0.10 \pm 0.01$ & $0.15 \pm 0.02$ & \\
\hline Ile & $0.11 \pm 0.02$ & $0.13 \pm 0.02$ & $<0.01$ \\
\hline Leu & $0.20 \pm 0.04$ & $0.18 \pm 0.03$ & \\
\hline Tyr & $0.48 \pm 0.05$ & $0.23 \pm 0.05$ & \\
\hline Phe & $0.19 \pm 0.02$ & $0.16 \pm 0.02$ & $<0.05$ \\
\hline Trp & $0.08 \pm 0.01$ & $0.08 \pm 0.01$ & $<0.05$ \\
\hline His & $0.08 \pm 0.02$ & $0.11 \pm 0.01$ & \\
\hline Lys & $0.33 \pm 0.03$ & $0.95 \pm 0.32$ & \\
\hline Arg & $0.17 \pm 0.04$ & $0.53 \pm 0.11$ & \\
\hline
\end{tabular}

Amino acid concentrations were calculated as an equivalent to $1 \mathrm{~g} w e i g h t / m l$. Mean+SE, $n=10$ significantly higher in broilers than in Niigata Jidori. On the contrary, no significant differences were found in concentrations of Thr, Ser, Gly, and Val, Met, Ile, Leu, Phe, Trp, and His. 


\section{5.mRNA Expression}

Figure 1 shows the mRNA expression of IGF-I in the liver of broilers and Niigata Jidori. mRNA expression of IGF-in Niigata Jidori was slightly lower than that in of broiler, however, this difference was not significant. Figure 2 and 3 shows the mRNA expression of breast muscle

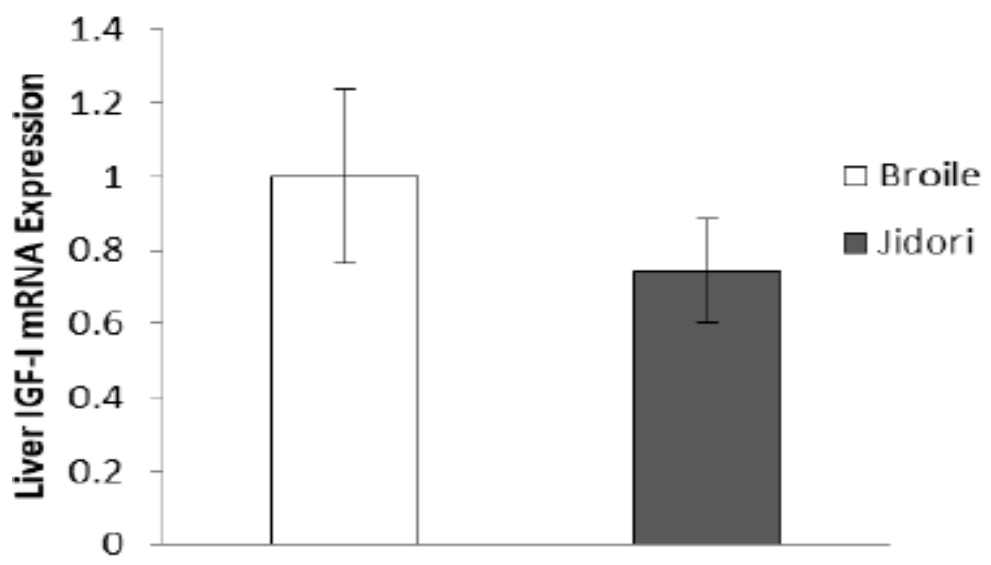

Figure1: Liver IGF-1 mRNA expression in broiler and Niigata Jidori. Values are mean $+S E, n=10$

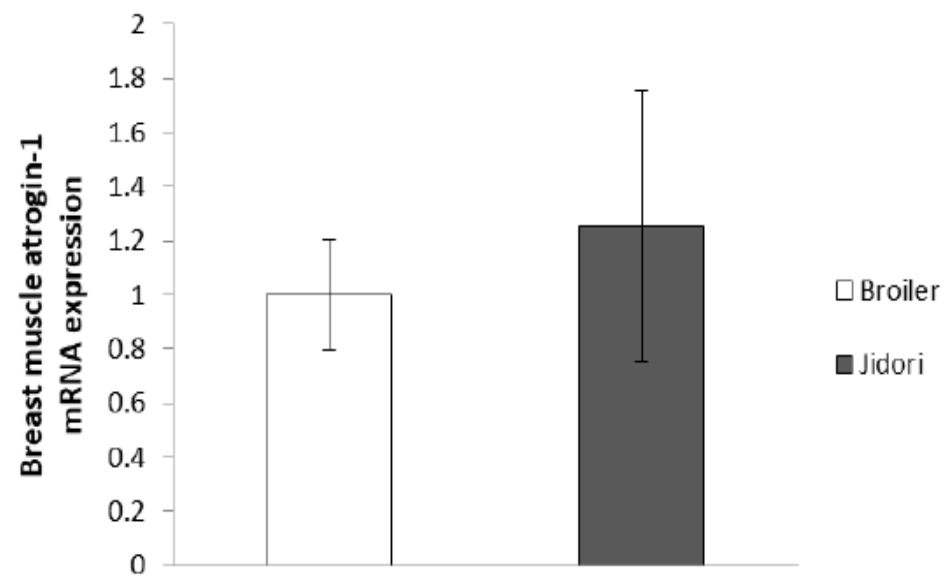

Figure2: Breast muscle atrogin-1 mRNA expression in broiler and Niigata Jidori. Values are mean $+S E, n=10$

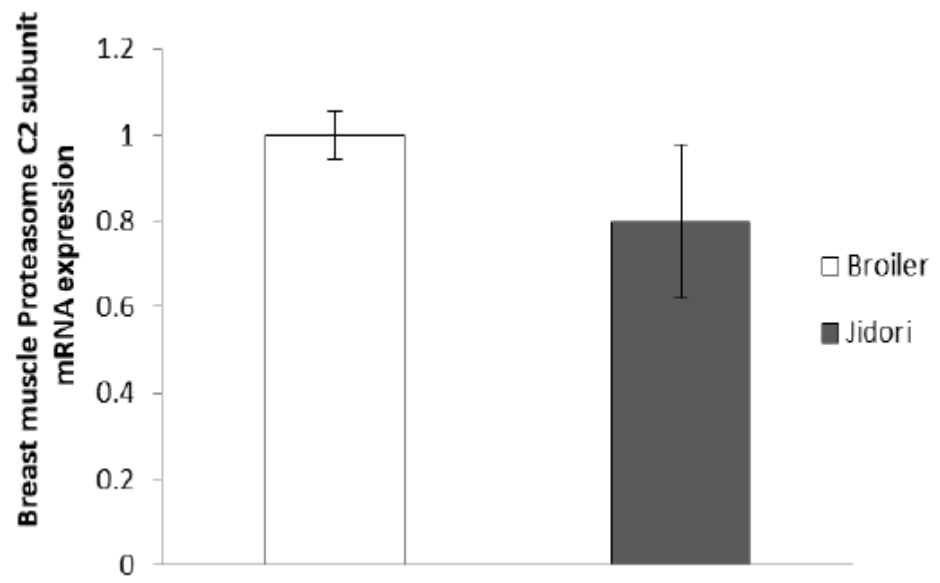

Figure3: Breast muscle proteasome c2 subunit mRNA expression in broiler and Niigata Jidori. Values are mean $+S E, n=10$ 


\section{DISCUSSION}

In the present study, growth performance was clearly different between broiler and Niigata Jidori (Table 3). BWG at 0-1 weeks and 12 weeks were significantly higher $(\mathrm{P}<0.01)$ in broilers than in the Niigata Jidori. Weights of breast muscle, thigh muscle, and liver were also higher $(\mathrm{P}<0.01)$ in broilers than in Niigata Jidori.

For all periods, FI of broilers was significantly higher $(\mathrm{P}<0.01)$ than that of Niigata Jidori. In general, BWG increases with increasing FI; therefore, increased BWG in broilers may be attributed to higher FI. However, FE of broilers was better $(\mathrm{P}<0.01)$ than that of Niigata Jidori. Lower BWG, FI, and FE in Niigata Jidori may be explained by the following; native chickens such as Niigata Jidori, which are not bred with focus on the growth rate, show limited feed utilization [13], hence, FE and BWG of broilers were better than those of native chickens [14]. Slow growth rates of native chickens have been previously reported by Rao and Pillai [15] and Paul et al. [16], and may possibly be explained by inadequate nutrient availability for these birds. With regards to FI, it is obvious that the amount of feed consumed by broilers was significantly higher than that consumed by Niigata Jidori. This is an expected observation because broiler chickens are heavier than Niigata Jidori. Additionally, it is well-known that, owing to their higher maintenance requirements and appetite, heavier strains consume more feed than do lighter ones. Concerning FE, it is clear that there was a significant difference between broilers and Niigata Jidori. The overall mean FE in broilers was significantly higher than that in Niigata Jidori. This means that broilers were more efficient in converting the feed to growth during the experimental period.

In our study, the main factor affecting weights of breast and thigh muscles appear to be the genotype of a chicken. Muscle weights (breast and thigh) of broilers were significantly higher $(\mathrm{P}<0.01)$ than those of Niigata Jidori. These findings are similar to those of previous reports [17, 18, and 19]. Poltowicz and Doktor [19] reported lower breast and leg meat yields in native chickens when compared with broilers. Similarly, we found that liver weight of broilers was significantly higher than that of Niigata Jidori, which is consistent with previous reports $[17,20]$.Concentrations of FAA and inosine monophosphate are thought to be correlated with the palatability of chicken meat [21,22]. Among FAA, Ala and Tyr concentrations were significantly higher $(\mathrm{P}<0.01)$ and Asp, Gln, and Cys concentrations were also significantly higher $(\mathrm{P}<0.05)$ in tissues of broilers than in tissues of Niigata Jidori.

Nitrogen retention (\%) was significantly higher in broilers than in Niigata Jidori, suggesting that FI in broilers not only improved BWG, but also had positive effects on nitrogen metabolism. This is similar to the findings of Labadan et al. [23]. Because of higher nitrogen retention, higher breast and thigh muscle weights were detected in broilers than in Niigata Jidori, and this may be due to increased protein synthesis and decreased protein (amino acids) degradation in broilers than in Niigata Jidori. However, no significant difference was found in mRNA expression of liver IGF-I between broiler and Niigata Jidori. A significant and positive correlation between mRNA expression levels and steady-state IGF-I gene expression was reported in domestic fowl [24]. It has also been reported that IGF-I stimulated muscle protein synthesis and suppressed proteolysis [25]. On the contrary, both atrogin- 1 and proteasome $\mathrm{C} 2$ subunit are proteolysis stimulating factors. In this experiment, however, mRNA expressions of these factors did not differ significantly between broiler and Niigata Jidori. These results, therefore, suggest that protein metabolism between broilers and Niigata Jidori is not so different.

\section{CONCLUSiON}

In conclusion, growth performance of broiler and Niigata Jidori differed significantly. Concentrations of some FAAs in the breast muscle were significantly different between broiler and Niigata Jidori. These differences in FAA concentrations are possibly responsible for the unique taste of the meat of Niigata Jidori. Higher nitrogen retention was found in broilers than in Niigata Jidori. However, no significant difference was observed in mRNA expression of IGF-I, atrogin-1, and proteasome C2 subunit between broiler and Niigata Jidori, suggesting that protein metabolism between broiler and Niigata Jidori is not so different. This study has shed light on the growth performance and nitrogen metabolism of Niigata Jidori. 


\section{REFERENCES}

[1] Miyakoshi Y, Honma N,Suzuki H.(2005): Breeding of "Niigata Jidori" for high quality meat crossbred TOMARU of Niigata native chicken. J Niigata Agr Res Inst.1-12.

[2] Fujimura S, Katsukawa M, Watanabe E, et al. (1991): Comparison of broiler, layer and Hinaidori. The Hokuriku J Zootech Sci. 62: 6-12.

[3] Mignon-Grasteau S, Beaumont C, E. le BihanDuval, et al. (1999): Genetic parameters of growth curve parameters in male and female chickens. Br Poult Sci. 40:44-51.https://doi.org/ 10.1080/00071669987827

[4] Mignon-Grasteau, Piles SM, Varona L.(2000): Genetic analysis of growth curve parameters for male and female chickens resulting from selection on shape of growth curve. J Anim Sci. 78:2515-24.https://doi.org/10.2527/2000.78102 $515 \mathrm{x}$

[5] Deeb N and Lamont.(2002): Genetic architecture of growth and body composition in unique chicken populations.J Heredity. 93:10718. https:// doi.org/10.1093/jhered/93.2.107

[6] Fujimura S, Koga H, Takeda H, et al.(1996): Chemical compositions of pectoral meat of Japanese native chicken, Hinai-jidori, and broiler of the same and marketing age. Anim Sci Technol.67:541-8.

[7] Rikimaru K and Takahashi H. (2010): Evaluation of the meat from HinaiJidori chickens and broilers: analysis of general biochemical components, free amino acids, inosine 5'-monophosphate and fatty acids. J Appl Poult Res. 19:327-33. https://doi.org/10.3 382/ japr.2010-00157

[8] Saneyasu T, Inui M, Kimura S, et al.(2016): The IGF-1/Akt/S6 Signaling Pathway is AgeDependently Downregulated in the Chicken Breast Muscle. J Poult Sci. 53:3 213-9.https:// doi.org/10.2141/jpsa.0150171

[9] González-Alvarado JM, Jiménez-Moreno E, Lázaro R, et al.(2007): Effect of type of cereal, heat processing of the cereal, and inclusion of fiber in the diet on productive performance and digestive traits of broilers. Poult Sci. 86:170515. https://doi.org/10.1093/ps/86.8.1705

[10] Ebling PD, Kessler AM, Villanueva AP, et al.(2015): Rice and soy protein isolate in prestarter diets for broilers. Poult sci. 94:2744-52. https://doi.org/10.3382/ps/pev279

[11] Fujimoto H, Fujita N, and Takada R.(2018): Effects of a rice diet and phytase addition on growth performance, tissue weights, phosphorus and nitrogen retention, and on liver threonine dehydrogenase, malic enzyme and fatty acid synthase activities in broiler. Anim Sci J. 89: 770-6.https://doi.org/10.1111/asj.1299 1
[12] Aviagen. Ross 308. Broiler, Nutrition Specifications. Aviagen, Huntsville, USA2014.

[13] Thammabut S. and Choprakarn K.(1982): Growth rate and protein requirement of Thai native chickens raised by small holder. Proceedings of the 20th Symposium Animal Science Conference, Kasetsart University, Bangkok, Thailand. 98-108.

[14] Leotaragul A, Punyawee S, and Duangjan S. (1996): Body weights, growth rate and mortality rate of Thai native chickens from high and low New Castle immunity's parents. The report of animal research for 1996. Department of Livestock Development, Bangkok, Thailand. 66-110.

[15] Rao KS and Pillai KJ. (1986): Dressing yields of broilers and country chicken reared under identical conditions. Anim Breed Abstract. 59: 893.

[16] Paul BP, Howlider MAR, and Bulbul SM.(1990): Comparison of meat yield between free range desi and broiler chicken. Indi J Anim Sci. 60:866- 68 .

[17] Rikimaru K, Ogawa S, Komastu M, et al. (2009): Effect of caponization on growth performance and carcass traits in Hinai Jidori chicken. J Poult Sci. 46:351-55.https://doi.org/ 10.2141/jpsa.46.345

[18] Brake J, Havenstein GB, Scheideler SE, et al. (1993): Relationship of sex, age and body weight to broiler carcass yield and offal production. Poult Sci. 72:1137 - 45. https://doi. org/10.3382/ps.0721137

[19] Poltowicz K, and Doctor J.(2012): Effect of slaughter age on performance and meat quality of slow-growing broiler chickens. Ann Anim Sci.12-4:612-31.https://doi.org/10.3382/ps.072 1137

[20] Jaturasitha SV,LeangwuntaA, Leotaragul A, et al.(2002): A Comparative Study of Thai Native Chicken and Broiler on Productive Performance, Carcass and Meat Quality. Deutscher Tropentag. 146.

[21] Karasawa Y, Aoki K, and Hirakata A. (1989): Free amino acids and purine compounds in leg and breast muscles from broiler, Satsuma, Satsuma cross and Kukin cross. Jpn PoultSci. 26:29-34.https://doi.org/10.2141/jpsa.26.29

[22] Nishimura T, Rhue MR, Okitani A, et al. (1988): Components contributing to the improvement of meat taste during storage. Agri Biol Chem. 52:2323-30.https://doi.org/10.10 80/00021369.1988.10869028

[23] Labadan JrMC, Hsu KN, and Austic RE. (2001): Lysine and arginine requirements of broiler chickens at two- to three-week intervals to eight weeks of age. Poult Sci. 80:599-606. https://doi.org/10.10 93/ ps/ 80.5.599 
Differences in Growth Performance and Protein Metabolism-Related Parameters of Broiler Chickens and Native Chickens (Niigata Jidori)

[24] Rosselot G, McMurtry JP, Vasilatos-Younken R, et al. (1995): Effect of exogenous chicken growth hormone (cGH) administration on insulin-like growth factor-I (IGF-I) gene expression in domestic fowl. Mol Cell Endoc. 114(1-2):1-166. https://doi.org/10.1016/03037207(95)96796-K
[25] Fang CH, Li BG, Wang JJ, et al.(1998): Treatment of burned rats with insulin-like growth factor-I inhibits the catabolic response in skeletal muscle. Am J Regu Integ Phys. 275:1091-98. https:// doi. org/10.1152/ajpregu. 1998.275.4. R1091.

Citation: Mohammad Ataur Rahman, Ryozo Takada, Differences in Growth Performance and Protein Metabolism-Related Parameters of Broiler Chickens and Native Chickens (Niigata Jidori) Takada ARC Journal of Animal and Veterinary Sciences. 2019; 5(3):21-28. doi: dx.doi.org/10.20431/2455-2518.0503003.

Copyright: (C) 2019 Authors. This is an open-access article distributed under the terms of the Creative Commons Attribution License, which permits unrestricted use, distribution, and reproduction in any medium, provided the original author and source are credited. 